\title{
A NEW RIODINID FROM PANAMA (LEPIDOPTERA)
}

\section{By Marston Bates}

Museum of Comparative Zoölogy, Cambridge, Mass.

\section{Genus Rodinia Westwood}

This generic name was proposed by Westwood (1851, Gen. diurn. Lep., II, p. 430) for a number of species, including Erycina calphurnia Saunders (1849, Trans. ent. Soc. London (1), 5, p. 216), which was designated as the genotype by Stichel (1909, Berl. ent. Zeits., 54, p. 42), although Saunders had proposed the name Euerycina for his species in 1859 (Trans. ent. Soc. London, (2), 5, p. 95), and restricted Rodinia to the other species listed by Westwood (l. c.). Stichel's action seems to be entirely in accordance with the provisions of the International Code of Nomenclature, even though it is not in strict accordance with the historical usage of the names involved.

Three "species" have been described in the genus: Erycina calphurnia Saunders (1849, l. c.); Euerycina delphinia Staudinger and Schatz (1888, Ex. Schmet., I, p. 248, pl. 89) and Rodinia (Euerycina) vulnerata Röber (1923, Stett. ent. Zeit., 84, p. 94). All were based on Amazonian material, and as only a few specimens are known, the status of these names is uncertain. The discovery of a related form in the rain forest of Panama is surprising.

\section{Rodinia barbouri sp. n.}

8. The ground color is dark grey; the upper side of the forewing has a straight, white, lavender-bordered, median band, which does not quite reach the costal margin, and ends on the outer third of the inner margin; the lower two thirds of the outer margin is bordered by blue. The outer margin of the hindwing is completely margined by blue, and the tail is entirely blue except for an apical fringe of white scales. An orange band, which begins at the base 
of the cubital stem and gradually widens, ends on the inner margin between veins $\mathrm{Cu}_{2}$ and $2 \mathrm{~A}$; the white median band, which begins on the costal margin, becomes entirely blue where it joins the orange band. The under side is similar, except that the base of the wings is clothed with blue-grey scales, and the orange band of the hindwing is reduced to an elongate spot. Length of forewing, $23 \mathrm{~mm}$.

This species is similar to that described as Euerycina delphinia by Staudinger (l. c.). A male in the M. C. Z., from Macicore, Amazonas, which agrees very well with Staudinger's description and figure, has the outer margin of the forewing slightly concave, whereas in barbouri it is somewhat convex; the tail of barbouri is relatively shorter, and the outer margin of the hindwing is more evenly rounded; the white band of the upper side of the forewing is more uniform and narrower in barbouri. On the under side, the subapical white shading of the forewing of delphinia is lacking in barbouri, and the white band of the hindwing is narrower, the orange spot larger, than in delphinia. The names calphurnia and vulnerata were based on females, in which the markings are quite different.

Type, a male in the Museum of Comparative Zoölogy, from Barro Colorado Island, Canal Zone, 29. XI. 1934, M. Bates. 

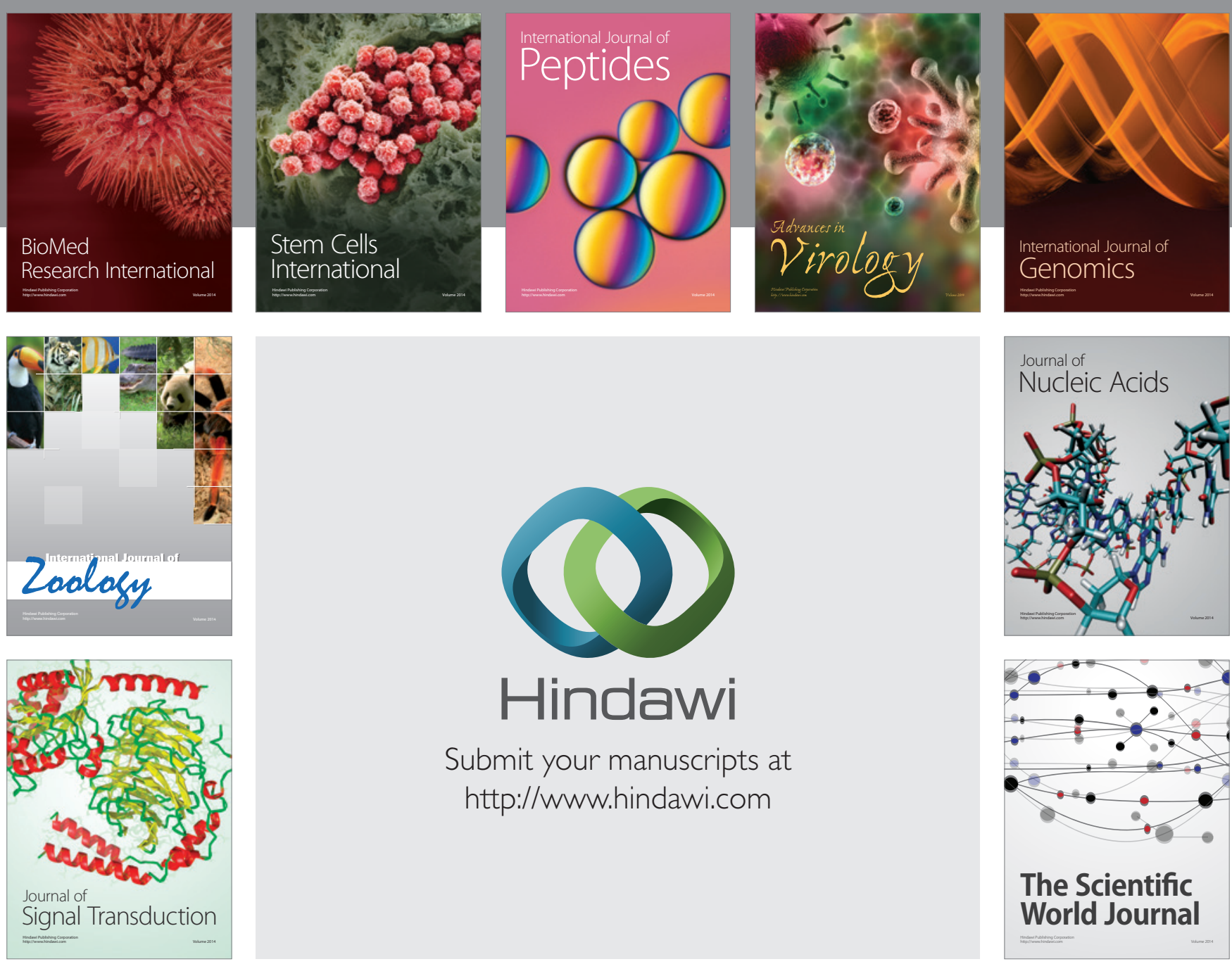

Submit your manuscripts at

http://www.hindawi.com
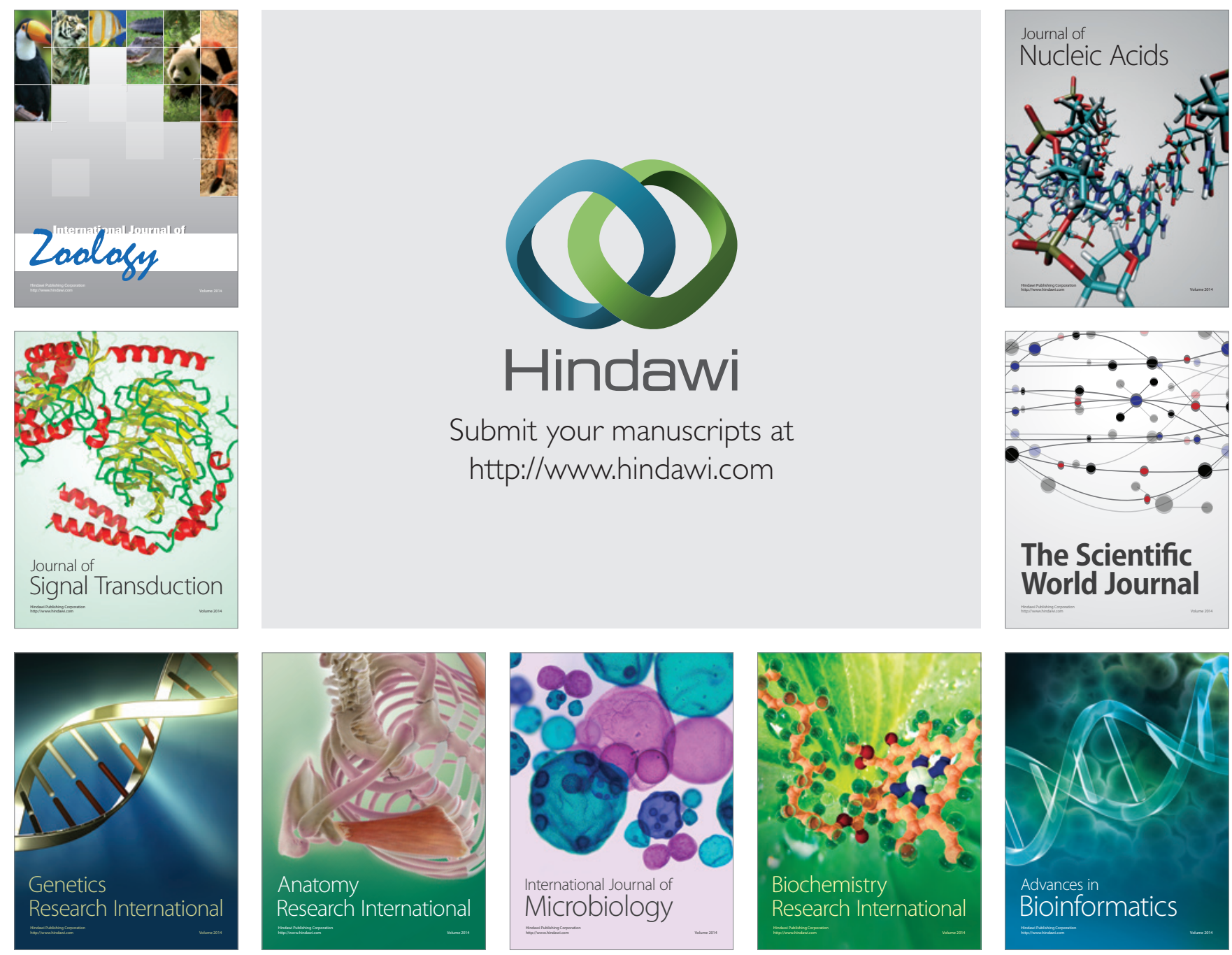

The Scientific World Journal
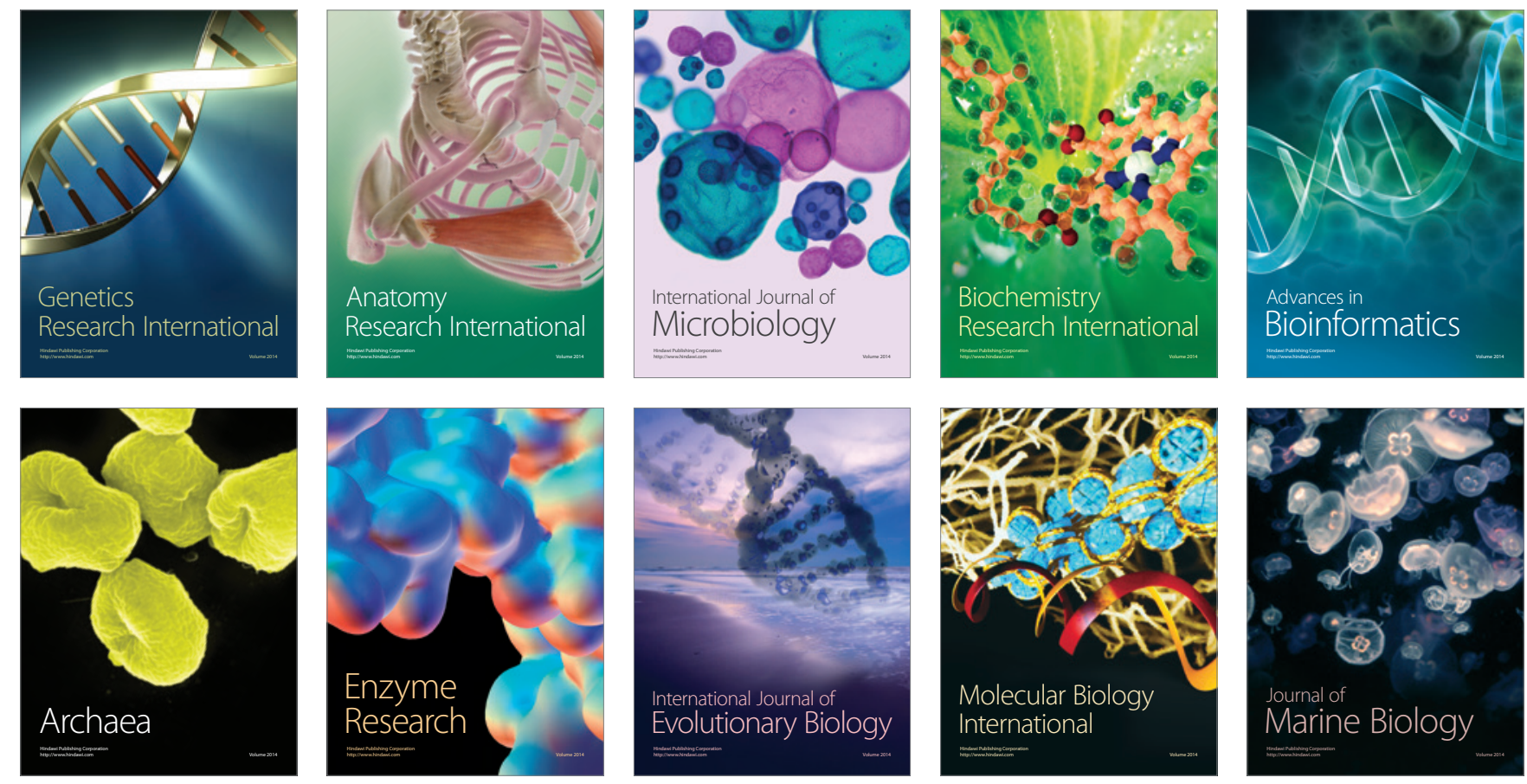